\title{
The Legitimacy of Ondoafi in Conflict Settlement of Customary Land Tenure in Sentani, Papua
}

\author{
Tri Mulyadi, Kamsi, Surwandono, Trisno Raharjo \\ Doctoral Program of Political Islam, Universitas Muhammadiyah Yogyakarta, Indonesia. E-mail: \\ sh.trimulyadi@yahoo.co.id \\ Faculty of Law, Universitas UIN Sunan Kalijaga, Indonesia. E-mail: kamsi@uin-suka.ac.id \\ Faculty of Law, Universitas Muhammadiyah Yogyakarta, Indonesia. E-mail: surwandono@umy.ac.id \\ Faculty of Law, Universitas Muhammadiyah Yogyakarta, Indonesia. E-mail: trisnoraharjo@umy.ac.id
}

ARTICLE INFO

Keywords:

Customary Land, Conflict,

Ondoafi, Papua, Ulayat

How to cite:

Mulyadi, T., Kamsi.,

Surwandono., Raharjo, T.

The Legitimacy of Ondoafi

in Conflict Settlement of

Customary Land Tenure

in Sentani, Papua.

MEDIA HUKUM, +62

274387656 (Ext. 220)

Article History

Received: 04/05/2019

Reviewed: 2/06/2019

Revised:

Accepted: 06/07/2019

\begin{abstract}
The charismatic power of ondoafi as a leader in customary government can determine the direction of the policy including the resolution of problems of indigenous people. In the new order Era, ondoafi was not involved further in resolving land issues, so he would not be labeled as part of the Free Papua Movement (OPM). In the Special Autonomy era, the roles of ondoafi got stronger as indicated by the privileges given by the government to indigenous people in Papua. This paper explores the roles of ondoafi in resolving the conflict over the customary land in Sentani, Jayapura, Papua, using a qualitative approach with secondary data. The result of the research shows that ondoafi could not resolve the conflict over the customary land in Sentani effectively due to the discrepancy of values between the conflicting parties. Nevertheless, ondoafi should become a mediator to resolve the conflicts between indigenous people and non-indigenous people; including privates or corporates and the central government. An ondoafi should be able to become a diplomat who can bridge the values differences between the conflicting parties and urge the conflicting parties to understand others' interests and values so that conflicts can be resolved in a peaceful manner.
\end{abstract}

DOI: $10.18196 / j m h .20190127$

Copyright (C) 2019 MEDIA HUKUM. All rights reserved.

\section{Introduction}

The issue of land in human life has a very important meaning because most of human life is very dependent on land ${ }^{1}$. In a number of regions in Indonesia, some ethnic groups also claim ownership of land commonly referred to as ulayat land. The existence of customary land is

1 Kobu, D. (2017). "Pelaksanaan Peralihan Hak Atas Tanah Berdasakan Hukum Adat Suku Tobelo di Kabupaten Halmahera Selatan". Journal Lex Crimen, VI (2), 36-43. 
recognized by the state as long as a certain community or ethnic group has a customary law community. Recognition of customary land rights also exists in Article 18B paragraph (2) of the 1945 Constitution which states: The state recognizes and respects traditional communities along with their traditional customary rights as long as these remain in existence and are in accordance with the societal development and the principles of the Unitary State of the Republic of Indonesia, and shall be regulated by law.

In addition, Article 2 paragraph (4) of Act Number 5 of 1960 concerning Basic Agrarian Law (BAL) states that "The implementation of the right control by the state may be delegated to the autonomous region and customary law community if deemed necessary and not being in conflict with the national interest in accordance with the provisions of Government Regulation." This regulation is the basis for regulating the customary land.

Conflicts as a result of sharp differences and severe conflicts of interest are caused by several backgrounds. First, there are different socio-political, economic and socio-cultural backgrounds that have a very strong influence. Second, there are thoughts that cause disagreement between each other. Third, there is an unsympathetic attitude towards a party, system and mechanism that exist in an organization. Fourth, there is a sense of dissatisfaction with the organization's environment, frustration, unhappiness, but people cannot do anything, and if they have to leave the group, they have to bear the risks. Fifth, there is an urge to exaggerate self-esteem, and it results in the desire to tell lies and make manipulation. ${ }^{2}$

Simon Fisher et al, explains the theory of causes of conflicts in society. The first is public relation theory in which the conflict that occurs is due to polarization, distrust, and hostility between groups in the midst of our society. The second is theory of principle negotiations in which the conflict is caused by incongruous positions and perspective differences about conflicts between the parties involved. The third is theory of human needs in which the conflict that arises in the community is caused by the struggle for basic human needs, such as physical, mental and social needs. The fourth is identity theory in which the conflict is caused by an identity that is threatened, or it is rooted in the loss of something and the past unresolved suffering. The fifth is theory of conflict transformation in which the conflict is caused by the presence of problems of inequality and injustice in the realm of social, economic, political and cultural life. ${ }^{3}$

The conflict over the transfer of ulayat land in Jayapura Regency was the result of the New Order government policy to accelerate the national development through economic development and transmigration program. Nevertheless, the central government of Indonesia has violated the Article 3 of the Basic Agrarian Act or UUPA in which the implementation and transfer of the land from the community was not in accordance with the customary law procedures.

At the beginning of the New Order government, in addition to Act No. 20 of 1961 concerning Revocation of Land Rights, there was the Regulation of the Minister of Home Affairs No. 15 of 1975 concerning the Acquisition of Land Rights. However, in its implementation, this regulation was misused by the authorities with many interests. Then, the Presidential Decree No. 55 of 1993 concerning the procurement of land for the implementation of construction in the interest of the public was enacted. This Presidential Decree regulates the establishment of committees of land acquisition consisting of government officials both central and regional, responsible for carrying out an inventory of land, estimating and proposing the amount of compensation, as well as holding discussions with landowners. If there is an objection from the landowner

\footnotetext{
2 Hidayat, D. N. (2002). Konstruksi Sosial Industri Penyiaran: Kerangka Teori Mengamati Pertarungan di Sektor Penyiaran. Makalah dalam diskusi “UU Penyiaran, KPI dan Kebebasan Pers, di Salemba 8 Maret 2003.

3 Fisher, S., Ludin, J., Williams, S., Abdi, I., Smith, R., \& Williams, S. (2000). Working with Conflict: Skills and Strategies for Action. Http://Lst-Iiep.Iiep-Unesco.Org/CgiBin/Wwwi32.Exe/[In=epidoc1.in]/?T2000=016268/(100).
} 
regarding the committee's decision, the community can raise the objection to the governor concerning only on the amount of compensation. ${ }^{4}$

According to the Information and Documentation Coordinator Elsam Ari Yurino, the transmigration program to Papua is proved to have a negative impact on the social life of indigenous people of Papua. The uneven transmigration and development program has resulted in an increase in the number of migrants to the land of Papua and a horizontal conflict between migrant communities and indigenous people of Papua. Therefore, according to him, the transmigration program must be stopped, and the transmigration policy that has been carried out so far should be evaluated. As an alternative solution to regional development, the central government must facilitate a program of cooperation among regions to strengthen local governments so that they can seek independent development, he said. One recommendation for the local governments, he added, is that they must also arrange a special regional regulation for Papua Province that encourages the assimilation of migrant residents into Papuan culture through formal and informal education. ${ }^{5}$

In the context of national law, the concept of national land law derives from customary law, so it recognizes the rights of customary law communities in various regions in Indonesia that have already existed and inhabited lands in Indonesia, even before Indonesia's independence. Although the definition of customary land rights is not explained in detail, Article 3 of the Basic Agrarian Act (UUPA) provides recognition of the existence of customary land rights in national land law. Customary land rights are the highest tenure rights in certain customary law communities over land that belongs to its citizens. The provisions in the Basic Agrarian Act also provide limits related to the existence of the rights of customary law communities. The limitations are in so far as they still exist, in accordance with the national and state interests, and should not be in conflict with the acts and other regulations of higher levels. ${ }^{6}$

The national land policy and transmigration program freed the ulayat land on the basis of the Regulation of the Minister of Home Affairs No.15 of 1975 concerning Provisions on the procedures of land acquisition. The land acquisition for the transmigration program in Papua has become a conflict over the transfer of ulayat land due to the lack of process according to customary law. The acquisition is carried out with a militarization approach and intimidation to traditional leaders in order to release their land. They finally felt disadvantaged because they did not fight back.

In the context of Papua, regulations concerning the existence of customary land are included in Act No. 21 of 2001 concerning Papua Special Autonomy which provides recognition of the existence of customary land rights in Papua. Letter s in Article 1 explains that customary land rights are the right of association owned by certain customary law communities over a certain area, which is the living environment of its citizens which includes the right to utilize land, forest, water and all their contents according to the regulations. Recognition of the rights in Papua is also emphasized in Article 38 paragraph (2) of the Papua Special Autonomy Law which states that economic efforts in Papua Province that utilize natural resources must be carried out by respecting the rights of the community, providing legal certainty for entrepreneurs and sustainable development stipulated by Perdasus. Based on these provisions, the government must synchronize the interests of providing protection for the customary land rights by ensuring legal certainty to entrepreneurs. Article 43 of the Papua Special Autonomy Law also gives legitimacy to the recognition of Papua Provincial Government to the land rights of customary law communities in Papua in which the article discusses the protection of the rights of the community ${ }^{7}$.

4 Fitriyah, F. (2016). Hukum Pengadaan Tanah Trasmigrasi. Malang: Setara Press.

${ }^{5}$ Ari, Y. (2015). Potret Kebijakan Pemerintah di Tanah Papua selama 46 Tahun Terakhir. Retrieved 29 May

2018, from http:/ /elsam.or.id/2015/12/ potret-kebijakan-Pemerintah-di-tanah-Papua-selama-46-terakhir

${ }^{6}$ Law No. 5 of 1960 concerning Basic Agrarian Act.

7 Law No. 21 of 2001 concerning Special Autonomy of Papua. 
Principally, the customary land in Papua should not be diverted by buying and selling, acquisition, building government infrastructure, privately owned plantations, and interests of other people who are not members of the customary law community. The transfer of ownership will only cause upcoming problems since to trigger the land conflicts in the community is a major violation of the prevailing customary law. However, there have been many cases of communal conflicts caused by the transfer of ownership of customary land. The conflicts that occur not only involve customary law community, but also non-indigenous people, private, and even the local and central government. This paper will answer the following question how to know the roles of ondoafi in resolving the conflict over the customary land in Sentani, Jayapura, Papua.

\section{Method}

This research is a qualitative research using documents as the main data source. The document referred to is state/government regulations regarding land, including important documents held by customary law community in Sentani. This research model did not use the population but certain cases and social situations that represent social similarities and the cases under study. This research is centered on the case of the conflict of ulayat land transfer in Sentani, Papua so that it is considered as an empirical sociological legal research. The primary data sources in this study were interviews with the head of tribes (ondoafi), the Customary Council of Sentani Tribe (DASS), members of the customary law community, and the settlers. Meanwhile, the secondary data were obtained from books as supplementary data for primary data sources. The secondary data sources of this research were data obtained by conducting literature studies, such as scientific books and documents. These secondary data were obtained from Land Agency of Regional Office of Papua Province, Land Agency of Jayapura Regency, Regional Government of Jayapura Regency, Jayapura District Court, and Notary/Land Deed Official. The collected data were then analyzed qualitatively.

\section{Analysis and Results}

\subsection{The History of Customary Land Conflict in Papua}

The conflict over the transfer of ulayat land occurred since Papua first integrated into the part of the Unitary State of the Republic of Indonesia. Land, employees' houses, office buildings that were previously controlled by the Dutch government were handed over to the Indonesian government. Land of ulayat rights from the customary law community in Papua was given at the time of a joint agreement (overenkomst) in 1956 and 1962 between the landowners of customary land and the Dutch Government. ${ }^{8}$ Land and buildings that were still used by the Papuan provincial government, the municipal government and Jayapura regency were recognized as state-owned land and not ulayat land because, according to the joint agreement, the Dutch government had provided compensation of 100,000 (one hundred thousand guilders) recognized by the customary law community as compensation of usage rights. ${ }^{9}$

The conflict over the transfer of ulayat land to the government, privately owned enterprises, and migrants from outside Papua is because the customary law community has different perceptions of understanding, giving rise to a conflict between the parties with the interests of each party and the state. The state controls the land based on Article 33 paragraph 3 of the 1945 Constitution. The constitutional foundation is the formation of the politics of national land law. During the New Order era, the transfer of the land was carried out with a militarization approach by intimidating traditional leaders to obtain a statement letter of release of ulayat land for the government program of transmigration. The conflict over the transfer of ulayat land in

8 Interview with Boas Enock, the ondoafi of Sosiri, (2018).

9 Interview with Bortolomeus Ongge, leader of Ongge Tribe. (2018). 
Jayapura, Papua has not been completely resolved from the New Order era until the Reformation period, so it received a lawsuit from the customary law community which was harmed.

Conflict over the transfer of customary land between different groups or tribes in Papua is often caused by the vague boundaries. Indigenous people or customary groups tend to determine their region based on the natural boundaries, such as rivers, trees, valleys, which can easily change due to natural phenomena. While the conflict within a customary group or tribe is often related to iniquity in distributing the compensation for the transfer of communal land. The iniquity often occurs when ondoafi is not involved in the process.

The land conflict become more complex when the conflicting parties cannot find the right formula to solve the conflict. For instance, in the case of conflict between investor or enterprise and the indigenous community. Investor or enterprise often accentuate the legal process of land transfer, but underestimate the existence of indigenous community and their customs, hence the indigenous people tend to occupy and blockade the access to the customary land. The construction project of many infrastructures; such as road and public service ought to be stopped due to threats from indigenous. The preceding conflicts later escalate and become security issue which involves violent or repressive actions between the conflicting parties ${ }^{10}$

The conflict of ulayat land transfer cannot be resolved easily because the young generation, as the successor to the existence of ulayat land, does not understand the true root of the conflict. Betina E. Schmidt and Ingo N. Schorder in her book Anthropology of Violence and Conflict stated that war, in the end, seen as a long-term condition and acts of violence between groups is clearly defined by the leading actor. This focus of perspective violence requires the idea that war is the result of an escalation that moves dynamically. ${ }^{11}$

Conflict over the transfer of ulayat land cannot be resolved by the positive law that applies, since the indigenous people acknowledge the customary authority as the decision maker rather than the local government. The conflict continues to move horizontally between traditional leaders and leaders of tribes whose territory of the ulayat land borders each other so that it spreads among the people of the customary law community. The community maintains the existence of ulayat land with their customary law. The conflict over the transfer of ulayat land to individuals from outside Papua who are not the members of customary law community has resulted in the denial of the release of customary rights, blocking action, a lawsuit against ulayat land released with a transfer process, an acquisition through a statement letter of the release of ulayat land made by traditional leaders, leaders of tribes, ondoafi/ondofolo and heads of districts from the government.

Widespread customary land conflicts that have not been resolved completely can evolve into political problems. The conflicts which have been previously considered as cultural or economic issue turn into political issues. A number of indigenous groups apply repressive approach to deal with the land conflict. They have successfully articulated the idea of secessionism, and form or join separatist groups which have been mobilized by the Free Papua Movement. Such a condition challenges the national sovereignty and demands the attention from the central government. ${ }^{12}$

\footnotetext{
10 Wee, V. (2002). Ethno-nationalism in process: Ethnicity, atavism and indigenism in Riau, Indonesia. Pacific Review, 15(4), 497-516. https:/ / doi.org/10.1080/0951274021000029396

11 Schmidt, B. E., \& Schroder, I. N. (2017). Antropology of Violencc and Conflict.

12 Miller, M. A. (2008). Rebellion and reform in Indonesia: Jakarta's security and autonomy policies in Aceh. Rebellion and Reform in Indonesia: Jakarta's Security and Autonomy Policies in Aceh. https://doi.org/10.4324/9780203888193
} 


\subsection{Ondoafi and Politics of Ulayat Land Control}

Ondoafi as the highest leader of customary law community oversees several leaders of tribes and has charismatic power as a leader in customary government. Position and great power determine the direction of policy in the government. On his duty, ondoafi is assisted by leaders of tribes, Abuafa, Ahona so that in making customary decisions, ondoafi asks for opinions from the elders and leaders of tribes. Enforcement of customary law was carried out with customary council meeting.

In the conflict of ulayat land transfer, ondoafi in his power summons Abuafa, Ahona and leaders of tribes in the customary trial. The decision in the trial must be obeyed by all parties. A trial of customary council of Sentani tribe (DASS) will be proceeded for the parties that do not obey. Ondoafi/ondofolo summons all parties involved in the conflict to the trial. The parties in the conflict must attend the invitation of the ondoafi to the trial of DASS to listen and respond to the testimony of the parties in the conflict. Likewise, the power and authority of ondoafi/ondoafolo can force attendance to the customary trial. If the parties are absent and do not suffice the number of attendees, the trial will be postponed and determined according to the results of customary deliberations in the trial. Ondoafi/ondoafolo will summon Ahona and leaders of tribes for the legitimacy of the ratification of the requirements for the release of ulayat land.

The role of ondoafi is very significant in the context of ulayat land ownership in Papua. In the New Order era, ondoafi did not dare to take control of ulayat land because he was worried that he would be accused of being part of the Free Papua Movement (OPM), but now the roles played by ondoafi are getting stronger. This is definitely because the authority structure in the government of Sentani customary law community is led by ondofolo or ondoafi assisted by Ketelo or Keselo as the head of the tribes (clan), also assigned as Abuafa (ondofolo's advisor) and Abu-akho that is ondofolo's assistant in leading the community (Akha-Peakhe). Ondofolo and kaselo also play the role as the elder of the village. The task of the customary government of Sentani tribe or "Holeinarei" is to find foods and look after children, maintain the community prosperity, culture, customs, and responsibility over the tribes.

Conflict involving particular ethnic is often caused by the disagreement in values, goals and interests. Based on the study of Papuans ethnography, most indigenous community in Papua believe that the power of god manifested in natural phenomena, such as wind, thunder, and rain. The community also believes that the spirit of the ancestors resides in inanimate objects such as soil, rocks, rivers, mountains and oceans, so that interfering the nature, including land is seen as a disrespect towards the ancestors. ${ }^{13}$ Such animism and dynamism have influenced the life of indigenous peoples in Papua for centuries. The existence of law and customary authority is aimed to guarantee the existence and culture of indigenous Papuans and their right to carry out the law in accordance with their belief. Such a tradition undeniably influences people's perceptions of the rule of law and customary authority compared to national law.

However, the customary community only recognizes the supremacy of customary law and authorities. The lack of knowledge among the community, particularly among ondoafis, regarding the positive law in Indonesia is also the factor that inhibit to peaceful settlement of the customary land conflict in Papua. On the contrary, non-indigenous people, corporates, and central government consider the district court and procedures mentioned on the positive law as the only way to deal with the land conflict, and tend to take the existence of the customary authorities for granted. In response to the blocking action carried out by the community, they sued the former owner of ulayat land with certificate issued by the National Land Agency. Buyers affected by the conflict defend their rights and interests by using proof of ownership. Such a disagreement has made the role of ondoafi in resolving the conflict become less effective.

${ }^{13}$ Marshall, A. J., \& Beehler, B. M. (2011). Ecology of Indonesian Papua. Tuttle Publishing. 


\subsection{The Role of DASS and Alternative Solutions for Conflict over Ulayat Land Transfer}

DASS as the organizers of the implementation of customary government authority, on the basis of the responsibility of ondoafi (executive) and kaselo/Katelo (legislative), maintains and fights for ulayat land to be transferred to the proper customary procedure. DASS has duty and customary role in protecting and maintaining the solidarity of Sentani tribe. The aim is to defend the basic rights of Sentani indigenous people as well as to overcome the internal barriers of the people and external influences to the condition of Sentani indigenous people. The authority of ondofolo is very broad to protect the community with special rights to prosper the customary law community covering the fields of religion, social, economy, politics and justice. With the intervention of the central and local governments, ondoafi no longer has strong authority. At present, customary government only plays a role in custom affairs. The shift of obedience of customary law community is a dilemma towards the authority of the community despite the Law Number 21 of 2001 on Special Autonomy for the people of Papua. In the implementation, the central and local governments have more roles than the customary government in relation to the rights of the customary law community.

For customary law communities, the first and foremost asset is land because the community itself is an agrarian society. An agrarian society is a community living dependently on land. Customary law community cannot be separated from land. If we talk about land, we indirectly talk about humans. In other words, if we talk about human existence, we indirectly talk about land. Land and this concept must be understood broadly and holistically, covering the earth even within certain wider boundaries that is the universe. In principle, land of ulayat rights in Papua should not be diverted by buying and selling, acquisition for the construction of government infrastructure, private plantations and interests of other people who are not members of the customary law community. The transfer of ulayat land is in reality carried out by members of customary law community and traditional leaders. The conflict occurrs because the process of transferring ulayat land is not in accordance with the procedures of customary law.

Considering the facts mentioned above, there is a very close relationship between the community and the land it occupies. This close and spiritual relationship allows the community to obtain the right to control the land, to use the land, to collect products from plants living on the land, and to hunt for the animals living there. Principally, ulayat land cannot be transferred by buying and selling. As a result of Papua being part of the Unitary State of the Republic of Indonesia (NKRI), ulayat land was transferred with the release and acquisition for government programs. Ulayat land have been freely traded, and the land ownership has been freely transferred to other parties, government, private companies and individuals.

In the Papuan context, particularly with regard to the customary authority of Sentani tribe, ondoafi, koselo (katelo), leaders of tribes consider the position of customary law to be higher than the national law, while investors consider that national law is higher. The strict difference because of maintaining the objectives and interests of each party from the customary law authorities and the investors is the main cause of a conflict over ulayat land. This condition will certainly trigger conflicts over the ownership of ulayat land between Sentani indigenous people in Papua and capital owners, private companies, as well as the government.

The trial of ulayat land transfer, as a medium for resolving conflicts, is carried out on the basis of requests from the parties to resolve the conflict. The parties must be present at the customary trial. If the number is not enough compared to the number of traditional leaders, the trial will be postponed for a period of time determined later by the customary council. The decisions of the customary trial must be adhered to by the parties involved in the conflict. As an alternative solution to a conflict over land in Sentani, Papua, there is a process that must be followed. The process in the customary deliberation is as follows.

a. The applicant must explain the allotment of the ulayat land which will be released provided that it does not cause disadvantages to the customary law community. 
b. The land to be released belongs to the customary law community. The rightful tribe must attach a map of land ownership and the history of the origin of the land.

c. The customary deliberation should be attended by ondoafi/ondofolo, leaders of tribes, Abufa, Ahona and the members of the customary law community involved in the conflict.

d. There is legitimacy of the ratification of the statement letter of customary release by ondoafi/ondoafolo, leaders of tribes, and traditional leaders on the basis of customary deliberations also known by the head of the district as the representative of the government.

e. Customary law communityy receives compensation from buyers given to the community through official report of the release as receipts of payments and distributed by customary parties. Each party signed as a sign of agreement in the release of ulayat land.

The importance of this transaction is transfer or delivery accompanied by cash payments from other parties at the same time. This transaction can be divided into three types according to its contents such as transfer of land with cash payments accompanied by provisions that those who hand the land over have the right to take back the land with payment of the same amount of money, transfer of land and cash payments without conditions, forever. And payment of land with cash payments accompanied by an agreement in which the land is returned to the former landowner if there is no other legal action after several harvests. This transaction is a legal action that is valid, meaning that in order to be entitled to legal protection, it must be carried out with the help of the head of the community so that it becomes clear.

Thus, during the transaction, the involvement of ondoafi who have better understanding on the positive law is prominent. Better understanding on the positive law can prevent ondoafi from making decisions that can lead to violations of the positive law. An ondoafi must become a figure who not only has legitimacy among the indigenous people, but also can be a mediator that bridges conflict, and transcends the differences of values between indigenous people nonindigenous people. The recognition of the special authority for the people of Papua given by the central government has turn out to be an epiphenomenon. The government, private sector or corporations, and immigrant communities in Papua should consider strategies that not only seeks to conserve the culture and values of indigenous Papuans, but to introduce and make the values be recognized and appreciated by non-indigenous people and corporations.

\section{Conclusion}

The conflict over the transfer of ulayat land is because the customary law community defends their ownership of communal rights for all customary law communities that cannot be transferred. The community is formed based on territory, customary law society, and a biological relationship. The solidarity between one another is very inseparable, even the members of customary law community who do not have a sense of togetherness towards other members will be exiled by the other members of the community. The customary law that applies is very firm, upheld, respected and further becomes a culture in customary law community by enacting a penalty obeyed by the community itself. The noble values in customs continue to be upheld because of the beliefs of the people. The leaders of the trials, ondoafi, and traditional leaders will always be obeyed and respected in every decision of the results of customary trials to enforce the authority of the customary government.

Nevertheless, ondoafi should become a mediator to resolve the conflicts between indigenous people and non-indigenous people; including privates or corporates and the central government. Disagreement in values is often becomes an obstacle to reconciliation. Considering that techniques and strategies used in conflict resolution not only encompass formal mediation and trials carried out on the table, but also informal negotiations performed behind the stage. An ondoafi should be able to become a diplomat who can bridge the values differences between 
the conflicting parties and urge the conflicting parties to understand others' interests and values, so that conflicts can be resolved in a peaceful manner.

\section{References}

Books:

Campion, B. B., \& Acheampong, E. (2014). The Chieftaincy Institution in Ghana: Causers and Arbitrators of Conflicts in Industrial Jatropha Investments. Sustainability, (6).

Farida, F. (2016). Hukum Pengadaan Tanah Trasmigrasi. Malang: Setara Press.

Fitriyah, F. (2016). Hukum Pengadaan Tanah Trasmigrasi. Malang: Setara Press.

Miller, M. A. (2008). Rebellion and reform in Indonesia: Jakarta's security and autonomy policies in Aceh. Rebellion and Reform in Indonesia: Jakarta's Security and Autonomy Policies in Aceh. https://doi.org/10.4324/9780203888193

Mudakir, I. S. (2015). Pembebasan Tanah Untuk Pembangunan Kepentingan Umum, Upaya Hukum Masyarakat Yang Terkena Pembebasan dan Pencabutan Hak. Jakarta: Jala Permata Aksara.

Pramukti, A. S., dan Widayanto, E. (2015). Awas Jangan Beli Tanah Sengketa. Yogyakarta: Pustaka Yustisia.

Schmidt, B. E., \& Schroder, I. N. (2017). Anthropology of Violence and Conflict.

Marshall, A. J., \& Beehler, B. M. (2011). Ecology of Indonesian Papua. Tuttle Publishing.

\section{Journal Articles:}

Alawode. (2013). "Determinants of Land Use Conflicts among Farmers in Southwestern Nigeria". Journal Research in Peace, Gender and Development (JRPGD), 3(4).

Paaga, D. T. (2013). “Customary Land Tenure and Its Implications for Land Disputes in Ghana: Case form Wa Weehau And Lambussie". International Journal of Humanities and Social Science, 3(18).

Mebri, J. A. (2017). “Kedudukan Hak Atas Tanah Masyarakat Hukum Adat Untuk Kepentingan Umum". Jurnal Ilmu Hukum, 13(25).

Bottazi, P. (2016). “Conflicts of Customary Land Tenure in Rural Africa: is Large-Scale Land Acquisition a Driver of 'Institutional Innovation?" The Journal of Peasant Studies, 43(5).

Beckert, B., Dittrich, C., \& Adiwibowo, S. (2014). “Contested Land: An Analysis of Multi-Layered Conflicts in Jambi Province, Sumatra, Indonesia." Austrian Journal of South-East Asian Studies, 7(1), 75-92. https://doi.org/10.14764/10.ASEAS-2014.1-6.

Dewi, R. (2016). “Gaining Recognition through Participatory Mapping the Role of Adat Land in the Implementation of the Merauke Integrate Food and Energy Estate in Papua, Indonesia. ASEAS" - Austrian Journal of South-East Asian Studies, 9(1).

Wee, V. (2002). "Ethno-Nationalism in Process: Ethnicity, Atavism and Indigenism in Riau, Indonesia." Journal Pacific Review, 15(4), 497-516. https://doi.org/10.1080/0951274021000029396. 
Kobu, D. (2017). “Pelaksanaan Peralihan Hak Atas Tanah Berdasakan Hukum Adat Suku Tobelo di Kabupaten Halmahera Selatan". Journal Lex Crimen, VI(2), 3643.

\section{World Wide Web:}

Ari, Y. (2015). Potret Kebijakan Pemerintah di Tanah Papua selama 46 Tahun Terakhir. Retrieved 29 May 2018, from http://elsam.or.id/2015/12/potret-kebijakanPemerintah-di-tanah-Papua-selama-46-terakhir.

Fisher, S., Ludin, J., Williams, S., Abdi, I., Smith, R., \& Williams, S. (2000). Working with Conflict: Skills and Strategies for Action. http://Lst-Iiep.Iiep-Unesco.Org/CgiBin/Wwwi32.Exe/[In=epidoc1.in]/?T2000=016268/(100).

Pemda. (1972). Serba-serbi mengenai Sejarah Masuknya Papua ke Indonesia. Retrieved 21 September 2018, from https://www.kompasiana.com/begawan. durni/54136718745513712b6c743d/serbaserbi-mengenai-sejarah-masuknya-Papua-keIndonesia.

Hidayat, D. N. (2002). Konstruksi Sosial Industri Penyiaran: Kerangka Teori Mengamati Pertarungan di Sektor Penyiaran. Makalah dalam diskusi "UU Penyiaran, KPI dan Kebebasan Pers, di Salemba 8 Maret 2003.

\section{Regulations:}

Law No. 5 of 1960 concerning Basic Agrarian Act.

Law No. 21 of 2001 concerning Special Autonomy of Papua. 